\section{DIGITAL COMMONS \\ @ UNIVERSITY OF SOUTH FLORIDA}

\section{ABO: Interactive Journal for Women in the Arts, 1640-1830}

Volume 8

Issue 2 Volume 8, Issue 2 Fall 2018

Article 2

2018

\title{
Reading Her Queenly Coiffure: A Collaborative Approach to the Study of Marie-Antoinette's Hairstyles
}

\author{
Hélène Bilis \\ Wellesley College, hbilis@wellesley.edu \\ Jenifer Bartle \\ Wellesley College, jbartle@wellesley.edu \\ Laura M. O'Brien \\ Wellesley College, lobrien@wellesley.edu \\ Ruth R. Rogers \\ Wellesley College, rrogers@wellesley.edu
}

Follow this and additional works at: https://digitalcommons.usf.edu/abo

Part of the Digital Humanities Commons, Dramatic Literature, Criticism and Theory Commons, Educational Methods Commons, Feminist, Gender, and Sexuality Studies Commons, and the Literature in English, British Isles Commons

\section{Recommended Citation}

Bilis, Hélène; Bartle, Jenifer; O'Brien, Laura M.; and Rogers, Ruth R. (2018) "Reading Her Queenly Coiffure: A Collaborative Approach to the Study of Marie-Antoinette's Hairstyles," ABO: Interactive Journal for Women in the Arts, 1640-1830: Vol.8: Iss.2, Article 2.

https://doi.org/10.5038/2157-7129.8.2.1189

Available at: https://digitalcommons.usf.edu/abo/vol8/iss2/2

This Digital Humanities is brought to you for free and open access by Digital Commons @ University of South Florida. It has been accepted for inclusion in ABO: Interactive Journal for Women in the Arts, 1640-1830 by an authorized administrator of Digital Commons @ University of South Florida. For more information, please contact digitalcommons@usf.edu. 


\title{
Reading Her Queenly Coiffure: A Collaborative Approach to the Study of Marie- Antoinette's Hairstyles
}

\author{
Abstract \\ Four colleagues--a faculty member, a digital services librarian, a research librarian, and a curator of \\ Special Collections--take turns describing their role in creating an undergraduate student project around \\ an eighteenth-century almanac that belonged to Marie-Antoinette. In recounting the steps taken, the \\ collaborative process, the student research, and the analysis of the contents of the Trésor des Grâces \\ almanac, we share the lessons learned for completing a digital exhibit over the course of one semester.

\section{Keywords} \\ Digital projects, Marie-Antoinette, material culture, eighteenth century, almanacs, undergraduate research, \\ faculty collaboration

\section{Creative Commons License} \\ (c) (i) (5)
}

This work is licensed under a Creative Commons Attribution-Noncommercial 4.0 License 


\section{Introduction (Perspective: Hélène Bilis, French Faculty)}

This essay offers a discussion of the merits and challenges of a collaborative digital project, both as a means to an instructional end and as a digital humanities project in its own right. With the goal of communicating the process of design, instruction, production, and evaluation — and providing clarity about the labor performed by each collaborator - four colleagues take turns describing their roles in guiding the students' research on the poufs. Part retracing the steps and approaches taken in creating this project, part analysis of the almanac's contents, and part reflection on what was learned throughout the process, this essay recounts the experiences of a cross-campus collaboration to produce the open-source digital exhibit, "Between Hairstyle and History: Understanding the Engravings in Marie-Antoinette's Almanac, Le Trésor des Grâces" (http://scalar.usc.edu/works/des-coiffures-pour-lhistoire/index).

Beyond Marie-Antoinette's apocryphal quip, "let them eat cake," and her execution on the scaffolds of the guillotine, if undergraduates know anything about the ill-fated French queen, they point to her flamboyantly vertical hairstyles. Hollywood has often enough encapsulated the decadence of late eighteenth-century Versailles through the towering coiffures of the Bourbon queen and her admirers. Recently, more refined settings have catered to the thrill of the French court's outlandish behaviors. For instance, the Victoria and Albert Museum of Art and Design in London has created an internet game where browsers can design their own elaborate eighteenthcentury wigs over the head of what resembles an engraved image; they can select up to five colors of powder, and adorn the hair with a variety of decorations, including a sailboat, ostrich feathers, flowers, and velvety ribbons.

Students are often surprised, therefore, to learn that there is more to the extravagant hairstyles than meets the eye. Marie-Antoinette and her hair have loomed large in a course I have taught regularly for the last ten years in the French Department at Wellesley College, entitled, "Long Live the Queen!: Women, Politics, and Power Under the Ancien Régime.” During the thirteenweek semester, students examine political, artistic, and literary portrayals of queens, princesses, and mistresses in an age when the male royal body became the defining model of sovereignty. It was not, however, until colleagues and I devised a digital project around the queen's hairstyles that students were able to decipher the many meanings attached to Marie-Antoinette's fanciful locks and understand how the queen's body was a major site of political communication.

The present essay recounts a cross-campus collaboration around a 1780 almanac thought to have belonged to the Bourbon queen. Le Trésor des Grâces, ou, la Parure de Vénus: mis à jour par le favori du beau sexe offers a calendar and list of saint's days - which you would expect from an almanac - but also includes eleven engravings of a young female figure who resembles MarieAntoinette. Each illustration presents a woman's head adorned by a vertical hairstyle - a poufbearing a distinct title after which the style is named. Through a collaboration with French Department faculty and students, a research librarian, the rare books curator, and the Digital Library Services Librarian, students decoded the references contained within the eighteenthcentury luxury almanac. In doing so, they learned to consider material objects as vehicles for tracing cultural and political transformations, and they reflected on the process of creating a digital exhibit for historical documents. 


\section{Genesis of the project (Perspective: Hélène Bilis, French Faculty)}

Trained in a literature department, I had conceived of this course as a means of presenting advanced undergraduate French students with canonical works of the seventeenth and eighteenth centuries within the historical context of the rise of absolutism. The political changes brought about by the increasing focus on the male royal body in early modern France paradoxically occurred as three women - Catherine of Medici, Marie of Medici, and Anne of Austriagoverned the kingdom as regent queens. The initial syllabus moved back and forth between historical and fictional accounts of the status of women through a variety of genres. Among the key representations of female characters, I usually included novels, such as Lafayette's $L a$ Princesse de Clèves and Saint-Réal's Dom Carlos; fairy tales by Perrault and d'Aulnoy; tragedies such as Le Cid by Corneille and Bérénice by Racine; and excerpts of Saint-Simon's memoirs. These are all great works that I deemed any solid French major should have under her belt before graduating, and they offered a range of portraits of women in, or close to, royal power: some of the women are dangerous and destabilizing for the state, some are tragic victims, while others are role models of heroic accomplishment. The ample secondary bibliography on these canonical texts would further the students' understanding of the scholarly debates around the literary and political portrayals of women, and lead students to write 12-14-page research papers at the end of the semester.

Increasingly, however, I became aware of the steep curve students have to wrestle with in the "traditional" paper format. Even after multiple drafts, it was hard for all but the most advanced undergraduates to see the research paper as a valuable experience, something to draw from in future courses, share with parents and roommates, and return to with pride. In the foreign language classroom there are other complications as well. Students are still struggling to master the vocabulary and grammar of a new language, while also grappling with the articulation of a strong thesis as they organize their bibliographical sources. The foreignness of French history, often entirely new to them, heightens the challenge they face to gain a nuanced understanding of the assigned texts. Intrigued by experiential learning possibilities and recent work on "meaningful writing projects"1 for engaging students, I had begun looking for alternatives to the research essay. Serendipitously, Ruth R. Rogers, Curator of Special Collections, suggested there might be a project structured around a new acquisition in the library.

From my first encounter with Le Trésor des Grâces in the Special Collections reading room, I was excited about the possibilities it opened for students to engage with a material object that had belonged to one of the queens on our syllabus. The almanac seemed to carry a slice of the queen's eighteenth-century life. Indeed, beyond its colorful frontispiece (see fig. 1) designating its contents as a "Treasure of the Graces," [Le Trésor des grâces] and one of "the garments of Venus," [La parure de Vénus] including two cherubs embracing each other in a pastoral setting, the pages of Le Trésor revealed engravings of a woman bearing a soft resemblance to MarieAntoinette herself (see fig. 2 and fig. 3). 


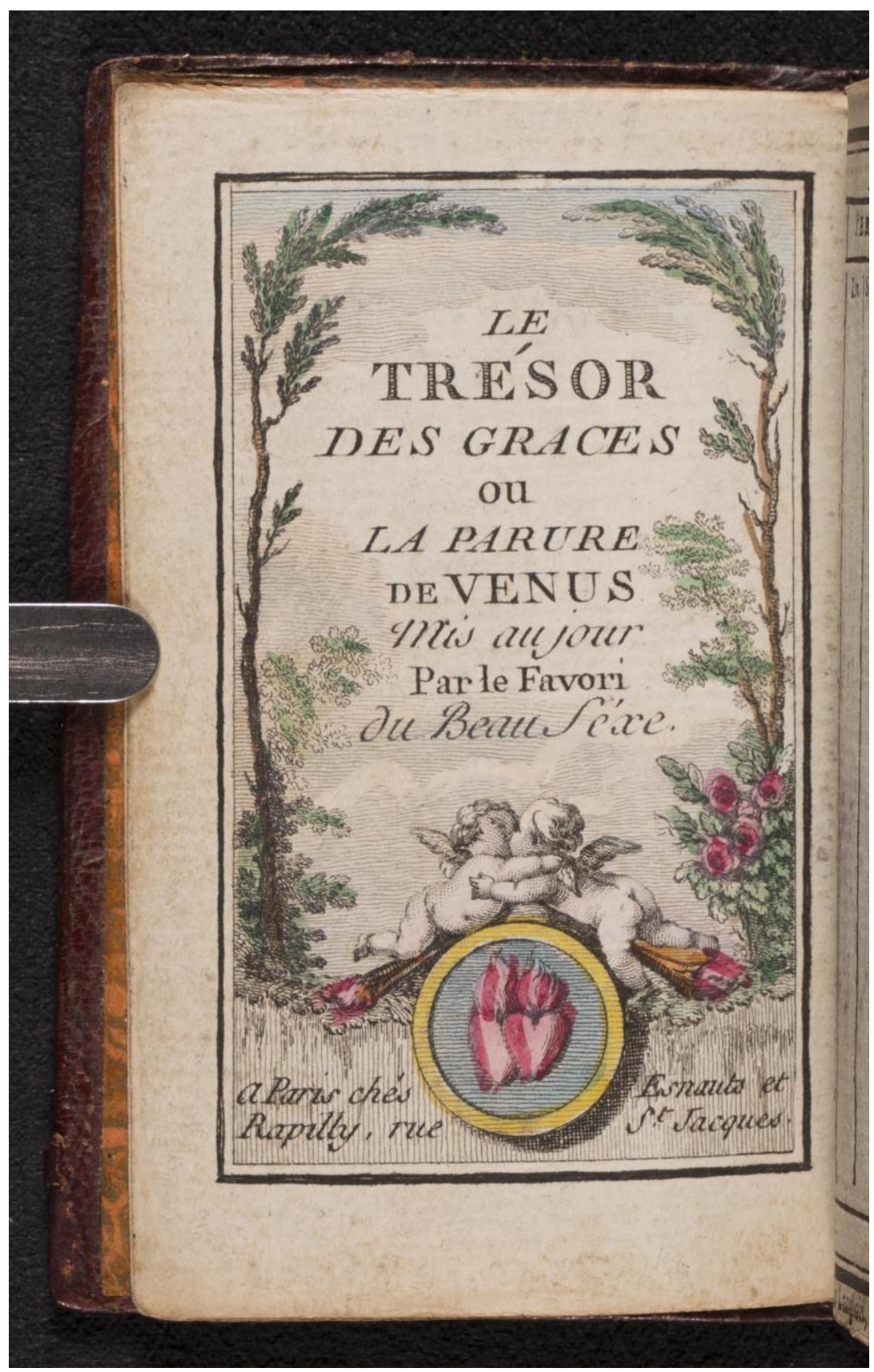

Fig. 1. Unidentified Artist, Le Trésor des grâces ou la parure de Vénus. Paris, Esnauts et Rapilly, [1780?] Engraved, hand-colored title page. Digital reproduction by Northeast Document Conservation Center. Courtesy of Wellesley College Library, Special Collections. 

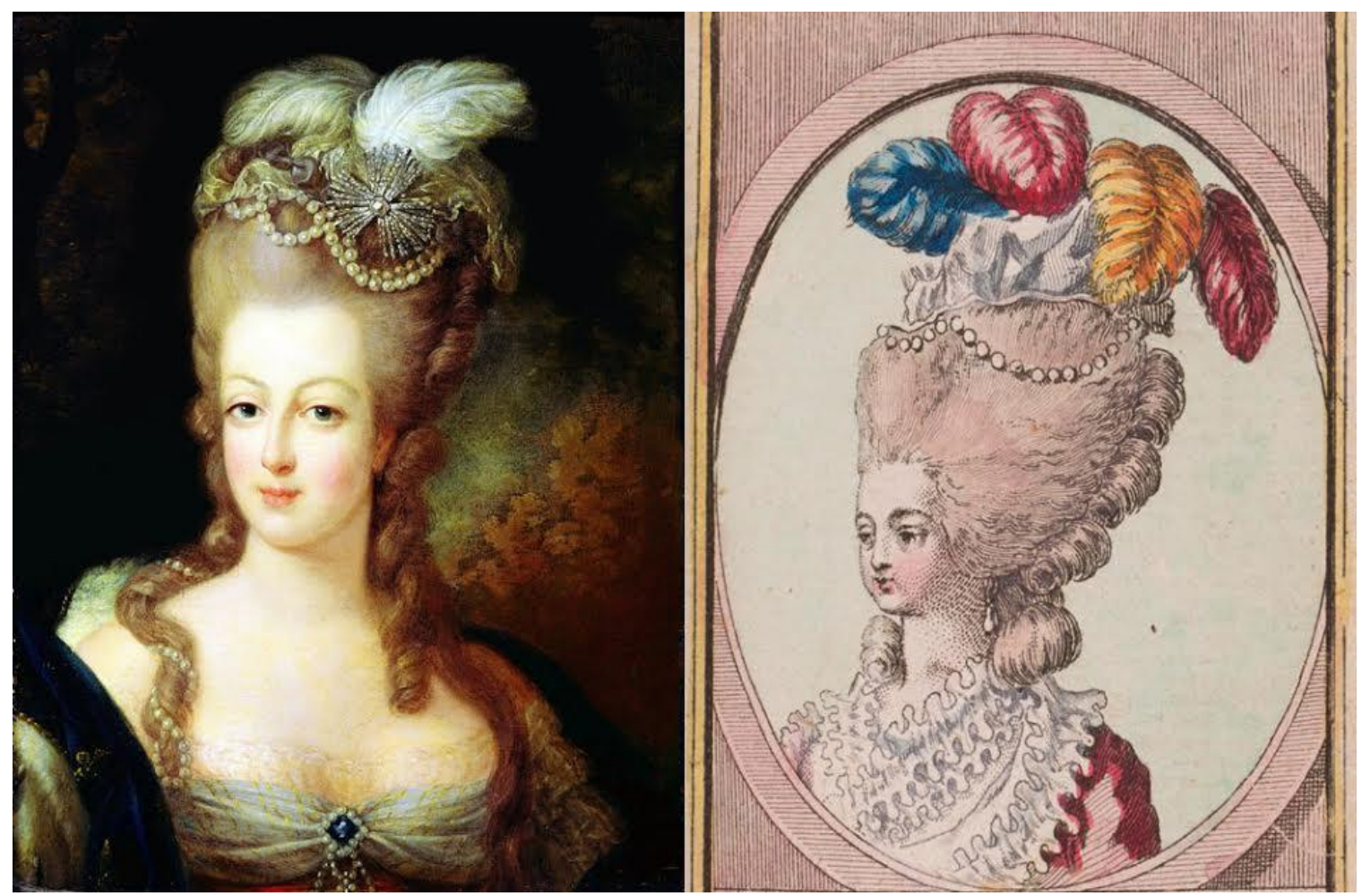

LEFT: Fig. 2. Jean-Baptiste André Gautier d'Argoty, Portrait of Marie-Antoinette of Austria (ca. 1775). Musée Antoine Lécuyer. Image Source: Wikimedia Commons.

RIGHT: Fig. 3. Unidentified artist, Coëffure à la Cléophile. Reproduction courtesy of Wellesley College Library, Special Collections. Composite image created by Marci Hahn-Fabris.

Each print in the almanac presents a woman wearing a different hairstyle along with an accompanying title. It was evident that while the interests reflected in the queen's almanac certainly differentiate Marie-Antoinette and her social milieu from those of the majority of French subjects living under the Ancien Régime, Le Trésor des Grâces has much to reveal regarding the cultural and sociological practices of elite Parisian women of the eighteenth century. Furthermore, while the almanac brings into focus the queen's unquestionably opulent tastes, it also illustrates that there is more to them than the frivolity generally assumed by critics seeking to deride her. In discussing Marie-Antoinette solely via secondary sources, as my class had previously done through a selection of historical texts and artistic portraits, students received only a narrow and inescapably sad image of her; centering our study of the queen through the almanac would allow us to engage more fully with the range of experiences she may have had.

Devising a new capstone course project around the almanac would harness student interest in the style, tastes, and miserable fate of Louis XVI's wife and help them understand the contradictory status of royal women in early modern France. Belonging to the highest echelons of political and economic power, queens were at once responsible for perpetuating the monarchical dynasty by giving birth to the next male heir and legally excluded from governance in their own name. Queens were held to impossible constraints regarding whom they must marry, where they must live, and how they must act. Amidst the chillingly narrow margins set for royal women, Marie- 
Antoinette's poufs are emblematic of queens' efforts to establish a French identity and express a sense of self beyond the constraints of their role.

In the spring of 2015, Wellesley College received a grant from the Andrew W. Mellon Foundation to support "Blended Learning Initiatives in the humanistic liberal arts." Broadly conceived, the grant sought to focus on the pedagogical benefits of combining traditional classroom models of learning with the use of new technologies. My library partners and I realized that an assignment based on the Trésor de Grâces would be an ideal opportunity to use digital technology — in this case an openly available digital publishing platform - to curate an exhibit on a rare material object. The digital exhibits undertaken by Janie Vanpée and Jacqueline Musacchio were important models for how we would shift between archival sources and digital tools. ${ }^{2}$ Previous work I had carried out around the Comédie-Française Registers Project led me to believe students would welcome the challenge of creating digital productions. ${ }^{3}$ We understood that a goal of the exhibit would be to share the almanac and the students' explanations of its contents with a broad public beyond the walls of our academic institution. Inspired by "enriched" editions of texts such as the Bibliothèque Nationale de France's digital Candide application for iPad and Folger Library Luminary digital editions of Shakespeare, we wanted to offer a reading of the almanac that would bring it to life by contextualizing and interpreting its contents for a broad public. ${ }^{4}$ We decided to create a digital exhibit of Le Trésor des Grâces, through which students would reflect on their movement between the material object - the almanac they could visit in the library and hold in one hand - and the version they would help exhibit online.

I received funding to digitize the almanac and cover expenses related to the project. Jenifer Bartle, the Digital Library Services Librarian, and I began discussing how to design the assignment and create the digital exhibit. Research and Instruction Librarian Laura O'Brien was enlisted to assist the students with their visual analysis essays. For Ruth Rogers, the Curator of Special Collections, the use of the almanac brought other opportunities: to promote rare books and Book Studies at Wellesley, and to increase student engagement with the study of material objects.

\section{The material book (Perspective: Ruth Rogers, Curator of Special Collections)}

In February 2015, in the course of my weekly perusal of rare book dealers' catalogs, a photo of a palm-sized gold-stamped red morocco binding (see fig. 4) caught my eye in a catalog issued by the noted Parisian bookseller Rodolphe Chamonal. Seduction by bindings is a common hazard of the rare book librarian's profession, but this one was not just any leather binding - it carried the arms of Marie-Antoinette on the front and back covers. 


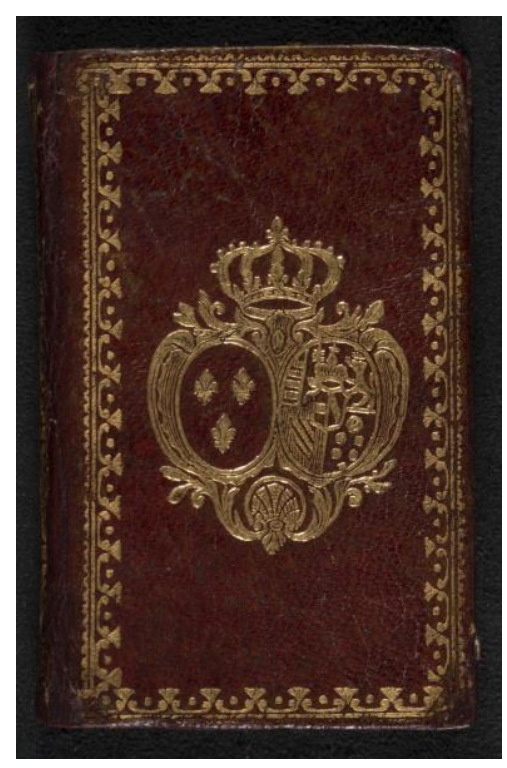

Fig. 4. Red morocco binding with royal coat of arms in gilt. Digital reproduction by Northeast Document Conservation Center. Courtesy of Wellesley College Library, Special Collections.

I might have been dubious about its authenticity, but Chamonal is highly respected in the trade, and had done ample bibliographic research on its provenance. The sentence, "Avait échappé à Grand-Carteret," piqued my interest further. Grand-Carteret is the most cited standard reference for French almanacs, so if this item was not listed in it, it had to be very rare. The emotional resonance of a physical object once owned by the ill-fated queen was undeniable, and was eloquently summed up by Chamonal in his description: "A touching and precious copy of this little almanac bearing queen Marie-Antoinette's coat of arms that Rose Bertin, her 'minister of fashion,' would not have condemned" ("Émouvant et précieux exemplaire aux armes de la reine Marie-Antoinette de ce petit almanach que n'aurait pas réprouvé Rose Bertin, sa 'Ministre des modes'."; 84; my trans.). The silent history of this object and its connection to its famous owner had me convinced that Wellesley College would benefit from this almanac. From my perspective as a curator of rare books at a women's college, this acquisition represented an opportunity to uncover the deeper political and cultural context of the elaborate hairstyles pictured within. Why did they carry such names as "Coëffure à la Veuve du Malabar," or "Coëffure à la RethelMazarin"? And why was this almanac of hairstyles not listed in the bibliography that includes hundreds of similar ones? I had a hunch that it could have been made up of sheets from other almanacs and printed expressly for the queen with its own title page, making it ostensibly a unique copy. Because engravings were expensive to produce, it was not an uncommon practice to reuse images in almanacs and other pictorial works. We already had in our collection several other French almanacs of varying quality, including one that was still in uncut sheets, published in Paris by Desnos around 1778. Desnos was a successful map publisher and entrepreneur who reused images and exported almanacs with new title pages to Berlin and Frankfurt as a way of capitalizing on the cachet of the stylish Parisian court. It became clear to me that this popular genre of book, consumed in great numbers by readers throughout Europe, would be a promising topic for course content and student research. 
An email to the dealer confirmed that the almanac was still available, and Monsieur Chamonal offered to reserve it for a few days while I gave it more thought. Could the high price for a tiny book whose initial impact had more to do with its aura than its text be justified? On the other hand, I could imagine the pedagogical uses of this item. It would be a visual complement to the existing print resources already in Wellesley's Special Collections, steadily acquired by purchase and gifts since the College's founding in 1870. These include eighteenth-century French and European books in the humanities, including novels by women, enlightenment philosophers, essays on women's education, and even seditious pre-revolutionary political pamphlets. This almanac could be a starting point for investigative research on the cultural climate of the Ancien Régime, European political history, and art history courses. Aside from the elaborate hairstyles and the people and places they were named for, it prompted questions about printing and publishing history that were equally important. Who purchased these little books, and what kind of market existed for them? Why were the images accompanied by popular verses and songs, and was there a subtext behind them? (Robert Darnton has written about the power of songs to communicate subversive political content.) Most intriguing, there were blank pages for every month with the heading "Perte et Gain," for the purpose of recording one's losses and wins at the gaming table (see fig. 5).

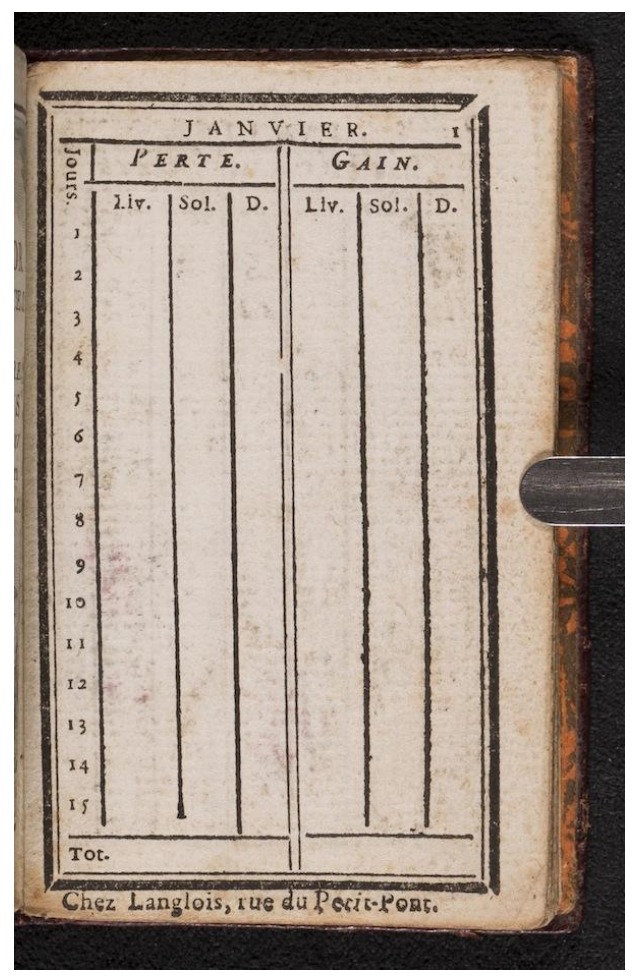

Fig. 5. Table for losses and wins at card games, Le Trésor des grâces ou la parure de Vénus. Digital reproduction by Northeast Document Conservation Center. Courtesy of Wellesley College Library, Special Collections.

I was convinced that the research possibilities and the interdisciplinary approaches to this precious almanac were worth the price, and with the support of a loyal and generous alumna, Lia 
Gelin Poorvu (Wellesley College Class of 1956), we purchased it for the Library. Thus with the support of a grant foundation (Mellon), a college program (the Andrew W. Mellon Blended Learning Initiative), the vision of the Curator of Special Collections, and the generosity of an alumna, the "Between Hairstyle and History" collaborative project was able to take shape.

\section{Devising the project—changes in texts, syllabus, and assignments (Perspective: Hélène Bilis, French Faculty)}

The basics of the assignment

In designing the content of the students' analysis of the images, I discussed with Jenifer Bartle and Laura O'Brien what could be realistically accomplished over the second half of the semester. We did not have the time or ambition to redesign the entire course, so our goal was to insert this project within an already existing class structure. (See Appendix I for a full version of the assignment.) Aspects we kept in mind:

1. Students are captive researchers for only as long as the course is in session. It's not fair to expect undergraduates to work on a project beyond the term's end so we needed to be realistic about how much they could accomplish. Although other aspects of the almanac, such as the frontispiece, the songs, the binding, and the "wins and losses" pages drew our attention, we decided to build the project solely around the hairstyles and assign one pouf per student. If students had not been able to complete the exhibit in one semester, they would have lacked the sense of closure that should ideally come with the last day of class.

2. A digital format favors brevity. Just as blog posts and wiki entries are most appealing when they summarize effectively, a digital exhibit should be succinct. Given that Wellesley is a small liberal arts college, I only had 12 students enrolled in the course. This allowed us to assign each one of Le Trésor's 11 engravings. For the student who was left without an image, we decided she would decipher an engraving of a hairstyle taken from a unique bound almanac made up from uncut and folded sheets in Special Collections. In her entry, the student reflected on the links between the queen's almanac and her assigned image, noting the popularity and prevalence of hairstyle engravings. If the class had been larger, I would have extended the assignment to cover the images among these uncut sheets.

3. Peers read peers: collaborative authorship. Each student worked individually on her assigned hairstyle, yet needed to keep in mind that each engraving was not a stand-alone image, but part of a collection in a common object. Thus the assignment must incorporate opportunities for students to inform themselves of their classmates' work. In a typical classroom, students discuss readings in common or engage in directed peer review activities, but it remains rare for them to read their fellow undergraduates as authorities on a subject. For this project, part of the assignment was to make connections 
between their assigned image and others in the almanac, i.e., to include a list of cross-references at the end of their entry and designate categories to which the pouf could belong (e.g., flowers; theater pouf; Voltaire allusion; mythology) to link the hairstyles by category. This shared effort developed teamwork and increased student engagement in the project.

4. Learning to value uncertainty in research. In most cases students found it difficult to know for sure if they had correctly interpreted the hairstyle. Even with seemingly straightforward examples taken from theatrical works, such as "à la Veuve de Malabar" or "à la Zaïre," it remained uncertain why MarieAntoinette would have been interested in the particular style at the date of the Trésor's publication. Students recognized more than one valid interpretation per style. This sort of open-ended research underscored the importance of considering the validity and authority of sources, of building a case, and of evaluating competing interpretations.

\section{Incorporating a digital project: changing the syllabus}

Incorporating the almanac allowed students to delve into the field of cultural studies in a way we had not done when the course was built around "great French works." We devoted more time to American scholars such as Desmond Hosford and Caroline Weber, whose research on MarieAntoinette's hair proved essential in devising the project. ${ }^{5}$ Students were encouraged to discover the richness of the material object and enrich their understanding of it through the scholarship on the satirical pamphlets that turned public opinion against Marie-Antoinette (pamphlets where her lavish locks are scathingly depicted). Standard reading on the subject by Lynn Hunt and Chantal Thomas became central to the course, with the effect of shifting our focus towards prerevolutionary queenship, rather than maintaining an equal balance across the early modern period from the sixteenth to the eighteenth centuries. ${ }^{6}$ Another redirection for our readings was secondary scholarship on early modern luxury goods and the almanac genre. New readings included Lilti on the invention of celebrities, DeJean on the rise of high fashion, and Goodman ("Republic of Letters") on salon culture. In short, students read more critical texts and fewer primary texts. Despite not writing a final research paper, they honed their research skills and engaged with scholarship more directly than in the first iteration where I chose the secondary texts for the course. Depending on their image, they had to seek out the sources that would be most relevant to them.

Incorporating the digital project meant reducing the course reading list roughly by half. Lafayette, Corneille, and Racine made the cut; I offered shorter excerpts by Saint-Simon and whittled our Bossuet and Perrault readings down to one piece rather than three. We read all the texts faster, all in the first seven weeks of our thirteen-week semester. Once the project was underway, we began focusing on the historical and critical texts that would enable students to situate the almanac within a clear cultural context.

Although our cultural studies approach deemphasized literature, students discovered that some of the hairstyles referenced popular theatrical works of the period. The project returned students to 
literary texts - albeit unexpected ones that I would not have thought of assigning, such as Voltaire's Zä̈re and Lemière's La Veuve de Malabar-which they then understood in a specific context and read with a sharper eye. Moreover, their knowledge of neoclassical French tragedy from the first part of the semester proved helpful for them to understand the lure of mythology and the influence of the Ancients on early modern audiences: turning to the semester's readings to decipher the almanac brought into focus how great literary texts are useful not just for "knowing the canon," but also for grasping a cultural climate and understanding the tastes of a time.

In designing the assignment, I accepted that more of our secondary texts would be in English, but conducted all of our in-class conversations in French. The foreign language classroom's focus on grammar skills had shifted, but did not disappear. To explicate their engraving, students learned vocabulary and expressions different from a typical essay-writing lexicon. They needed to stretch their skills to incorporate discussions of feathers, pearls, powder, and other accessories, as well as maps, readership, fashion, economics, and almanac trends. Additionally, by moving away from a traditional essay that a student writes strictly for her professor to a digital exhibit geared for any reader with access to the internet, students needed to focus on finding an appropriate style and vocabulary to fit a new format and audience.

\section{A turn towards cultural history: early modern almanacs}

Unequivocally, the biggest adjustment to the syllabus involved changing the kind of research in which students were engaged. Instead of spending time developing strong thesis statements for a final paper and assembling an accompanying bibliography, students started their research solely on the contents of their assigned image. Determining what form the final product of such an assignment would take involved turning to trusted library partners. On the one hand, we wanted students to engage with the almanac as a historical artifact, a luxury item they could hold in their hands and whose pages they could turn, like the queen herself must have done; and, on the other hand, they would need to think about how to present their assigned pouf in a broadly accessible digital format.

In the seventh week of the semester, the focus of the class turned to the study of early modern almanacs. Students learned that the pocket-sized fashion almanac was an elite genre in comparison to the widely available royal almanacs published for large-scale consumption in the seventeenth and eighteenth centuries. The almanacs of the age of Louis XIV, for instance, consist of large sheets of paper destined to be hung on a wall, closer to modern day posters or calendars, sold by the thousands in French cities near the end of every year; this type of almanac was short lasting, and meant to be replaced from year to year (Préaud). As Abby Zanger has shown in her study of royal nuptials, the widespread royal almanac often commemorated a major monarchical accomplishment and served the joint purposes of indicating dates and weather forecasts, as well as promoting the Crown's propaganda.

These almanacs-placards ensured communication from the King to his subjects throughout France and could be purchased from door-to-door salesmen who often sold them as end-of-year household gifts. ${ }^{7}$ Other almanacs, with the traditional purposes of foretelling the weather, the seasons, and giving advice on farming, gardening, and horoscopes, were also widespread. They differed markedly from the niche almanac, of which the Trésor des Grâces is an example: a 
booklet designed for a predetermined audience that develops an area or theme through its engravings and accompanying text. In the niche area, scholars have most often focused on Revolutionary almanacs, of which it is estimated that there are 400 extant copies, including two holdings in the Wellesley College Special Collections (see fig. 6-7) that students were able to consult for comparison to Marie- Antoinette's (Andries 205).

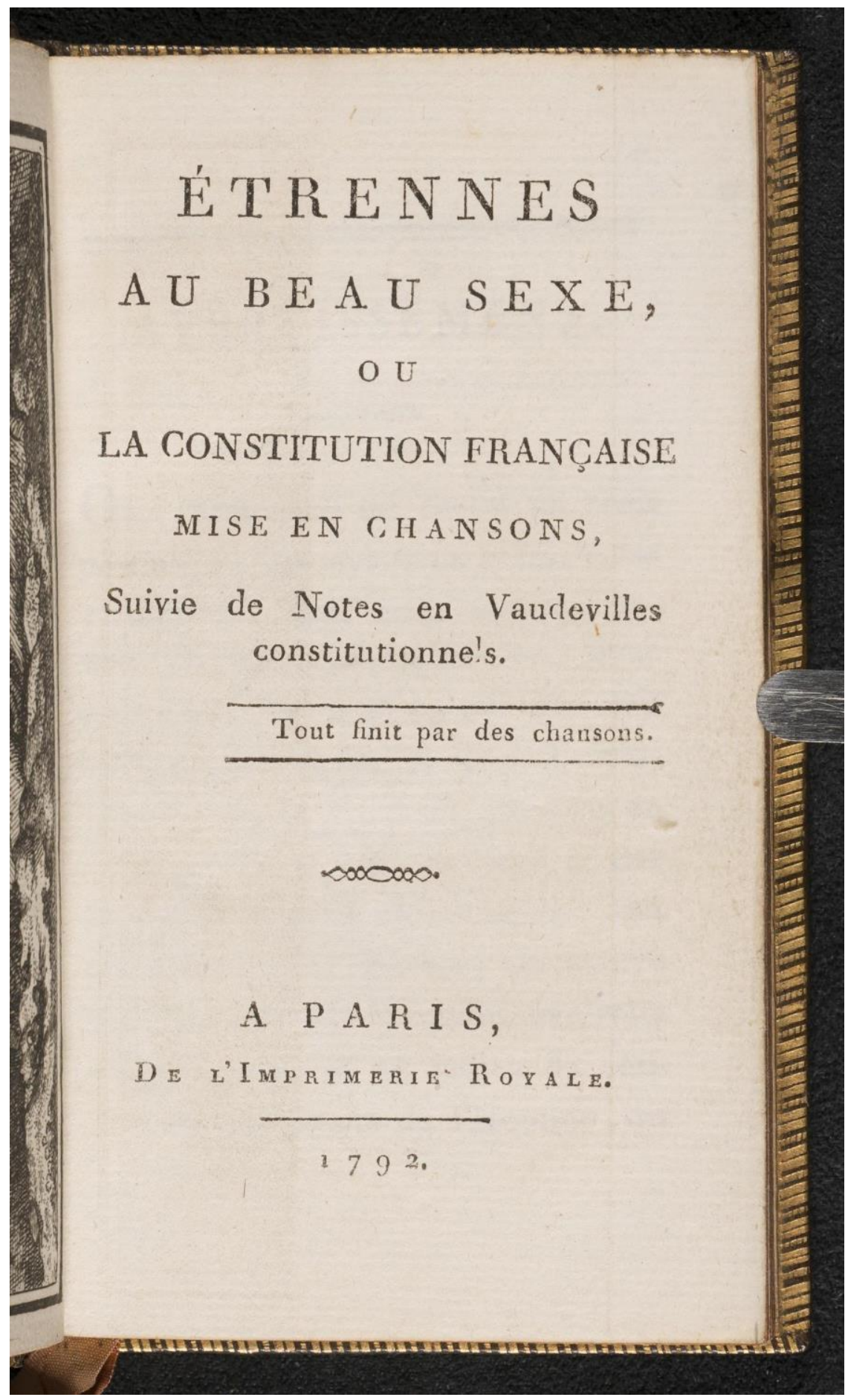


Fig. 6. Author Unknown, Etrennes au beau sexe, ou la constitution française mise en chansons [1792]. Digital reproduction by Northeast Document Conservation Center. Courtesy of Wellesley College Library, Special Collections.

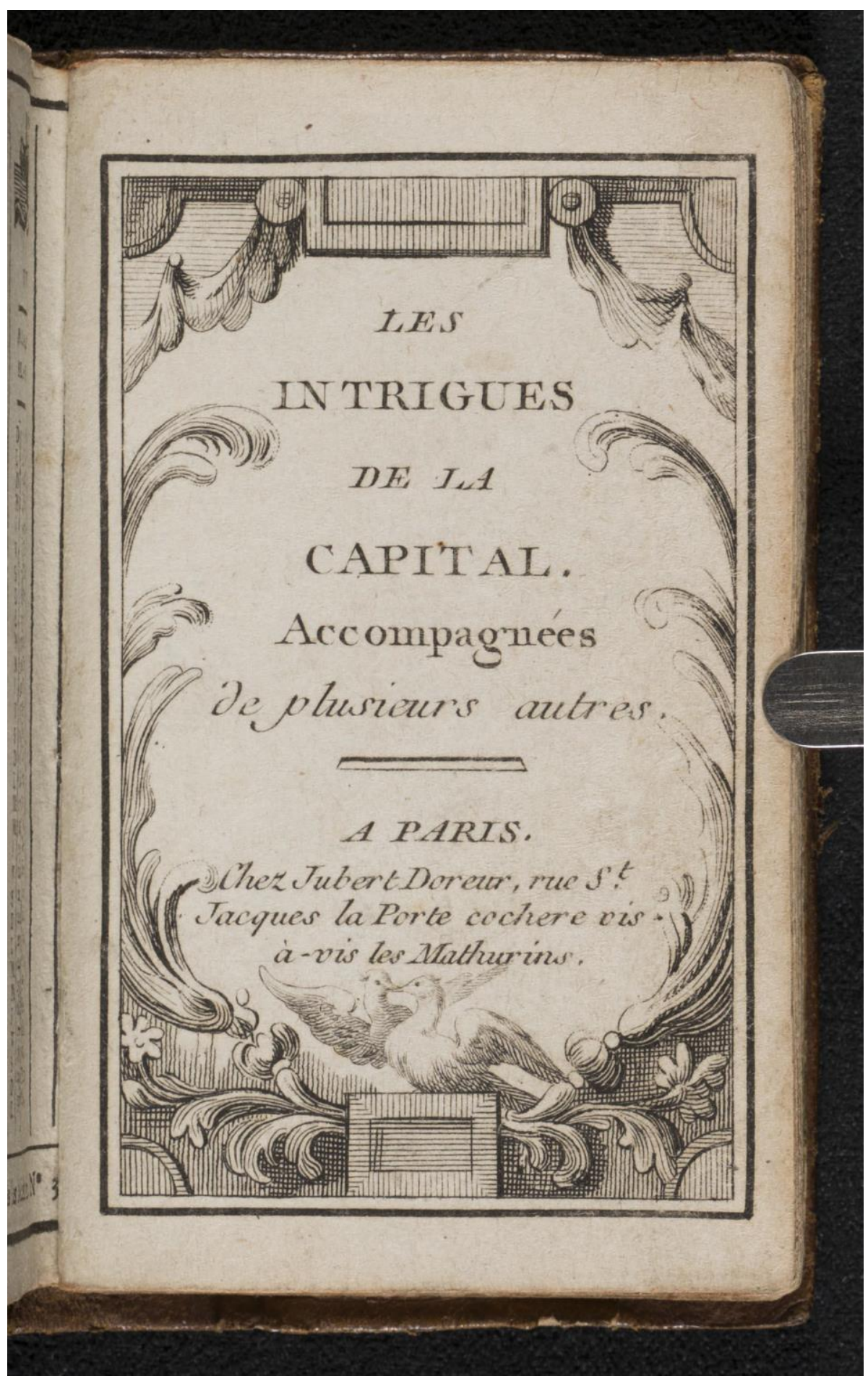


Fig. 7. Author unknown, Les Intrigues de la capitale, accompagnées de plusieurs autres. [Illustrée par Louis Binet] Paris: Jubert, 1788. Digital reproduction by Northeast Document Conservation Center. Courtesy of Wellesley College Library, Special Collections.

Le Trésor des Grâces belongs grosso modo to the category of the almanach galant, intended for a female reader with leisure time and disposable income. Almanacs of this sort are carefully printed, include selections of literary or romantic musical texts, and are expensive: they sold for around 36 sous, compared to two sous for the popular almanacs (Andries 206). The Trésor des Grâces in particular attests to the eighteenth century's growth as a period of consumerism and public interest in fashion. While historians have seen in Marie-Antoinette's hairstyles what Caroline Weber has described as “emblems of the monarchy's dark side: the absolutist power that enables a king capriciously to bankroll unbridled female acquisitiveness," the styles in the queen's almanac are varied and mostly modest (119). Le Trésor does not showcase the most excessive of hairstyles, such as those described as reaching up to the chandeliers at the theater or preventing a woman from riding in a carriage. The poufs in Le Trésor, instead, represent a broad cultural universe to which Marie-Antoinette belonged.

Having learned the basics of almanacs and their audiences in the early modern era, the class was ready to return to Special Collections to engage with our primary source.

\section{An introduction to Book Studies methods (Perspective: Ruth Rogers, Curator of Special Collections)}

Early in the process of this project, Professor Bilis and her students met with me in our Special Collections seminar room for an orientation to the eighteenth-century illustrated book. My role was to provide a deeper understanding of Le Trésor as a material object from the period and to prompt the students to ask some essential questions: who were the makers, the merchants, and the audience for this type of book? How do the physical characteristics of the book liminally convey information beyond the text, what Genette calls the "paratext"? Finding answers to these questions required students to possess a basic understanding of the book production economy in the eighteenth century - stressing that every book in the handpress period was a handmade object, not mass produced. Incorporating this critical information at the beginning of the project set up important scaffolding for the subsequent excavation of the social and political implications of the Trésor des Graces' text and images.

We started by examining related materials in Special Collections, including several other French illustrated almanacs and seventeenth-century English popular ones in order to establish a comfortable level of visual literacy (for more on visual literacy, see "Developing primary source and visual literacy in section 6). For example, we compared a 1693 edition of Partridge's Merlinus Liberatus (see fig. 8) to several other French eighteenth-century fashion almanacs, noticing that the English one contained agricultural forecasts, horoscopes and meteorological tables, news from France, and advice on health and illness. Even a student who has never before seen books such as these is quickly able to differentiate between those that look expensively made from those that look "homely" or rustic, based on typeface, format, paper quality, and image clarity. 
We could imagine that the audience for the Partridge almanac was quite different from the French ones. What did it suggest about the owner of the Partridge almanac that the pamphlet text sheets were folded lengthwise into a thin oblong, bound into decorated leather covers?

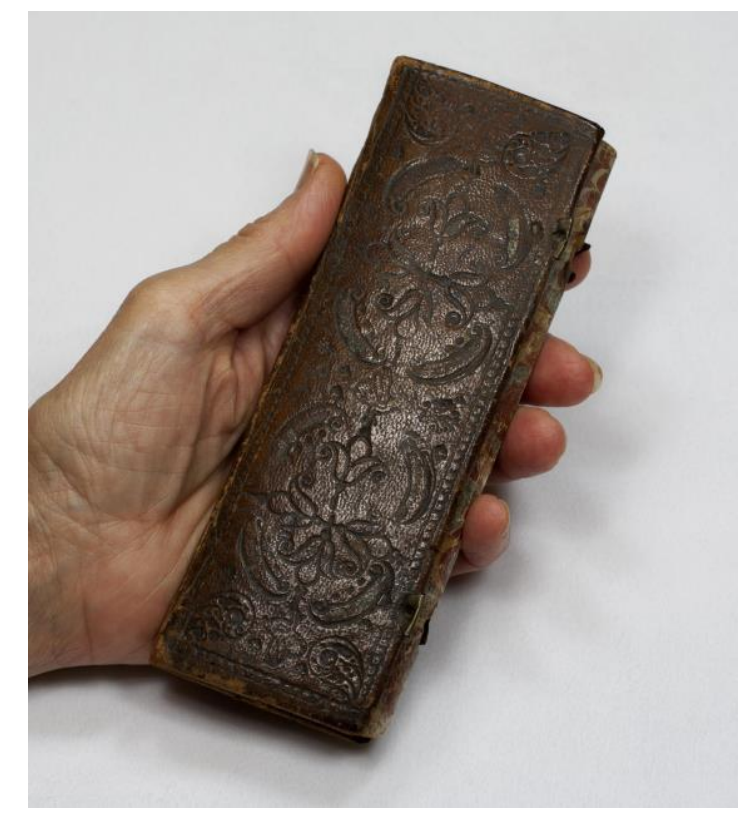

Fig. 8. Vest-pocket leather binding, Partridge, Merlinus Liberatus: Being an Almanack for the Year of Our Saviour's Incarnation, 1693. Photograph by Marci Hahn-Fabris. Courtesy of Wellesley College Library, Special Collections.

We established that this handy folded octavo format made it easier for a merchant or businessman to insert it into a vest pocket, while the little French almanacs were tiny enough to fit into a woman's purse or dress pocket. This visual exercise made the students think about the readers of these books: their level of literacy, their social status, and their ownership of books for practical purposes and personal entertainment. (For further reading on this, I recommend Martyn Lyons' A History of Reading and Writing in the Western World.)

It proved useful to examine students' other assumptions about books. For example, did they know that until the second quarter of the nineteenth century, book bindings were added and paid for by the owner, not the publisher? Or that the fine leather binding on Marie-Antoinette's almanac carried a coat of arms authorized for use only by her personal bookbinder?

For a deeper understanding of the economics of making books in the handpress period, we covered physical features of books such as paper size, type imposition and format of the page, typefaces, and illustration methods. We handled sheets of mold-made paper with chain lines and watermarks, and discussed the equipment, labor, and raw materials needed to produce it. Demonstrating with an actual metal plate and a carved woodblock, the class received an overview of graphic techniques, and the making of woodcuts and engravings as illustration methods. Once they understood that intaglio and letterpress had to be accomplished on separate presses by two different artisans, it was evident why printing engravings made a book more expensive for the consumer, which informed our discussion about privilege and classes of 
readers. Students could also better appreciate the need for saving and recycling images, which lead to a secondary market of re-used engravings for other books, sometimes issued by the same publisher, as one student discovered when researching her particular illustration.

Next, in order to comprehend how the Marie-Antoinette almanac was printed in such a small size (12mo or duocedimo), we took apart a little model that I had made ahead of time with a folded full sheet of paper and pasted on images (see fig. 9).

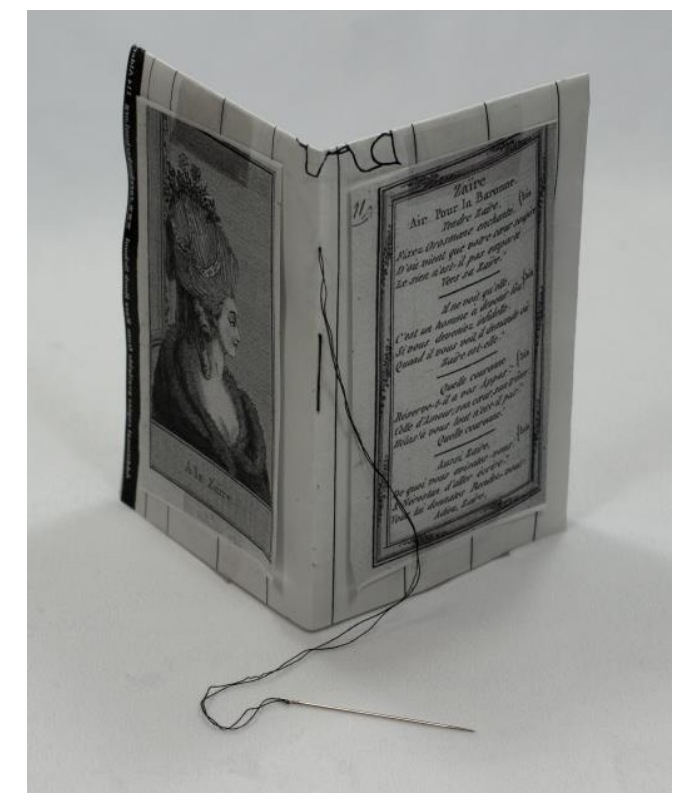

Fig. 9. Mock-up of the almanac to demonstrate format and imposition. Courtesy of Ruth Rogers. Photograph by Marci Hahn-Fabris.

By incorporating this hands-on lesson, students could more easily grasp the labor that went into publishing a single book in an edition of 700-1000 copies. Most of us in the twenty-first century have not been exposed to the highly specialized eighteenth-century technologies of papermaking, typesetting, printing, and binding a book. With a better appreciation of the craft involved, the perfection of the tiny personalized almanac with hand-colored engravings was all the more remarkable. I recommend showing students the plates from Diderot's Encyclopédie, which provide a richly detailed snapshot of the world of papermaking, printing, and binding in the mid-eighteenth century. ${ }^{8}$ (If one does not have access to type and a hand press, a good text on formats and imposition is Gaskell.)

The final part of the session was devoted to looking at other books from the decade in which the almanac was published in order to get a sense of the French illustrated livre de poche. We are fortunate to have in Wellesley's collection some fine examples of intimate rococo luxury books depicting pastoral fantasy, such as Le Temple de Gnide (see fig. 10) and Les Baisers (see fig. 11). The opulent engravings by masters like Charles Eisen are more impressive than the poetry. 


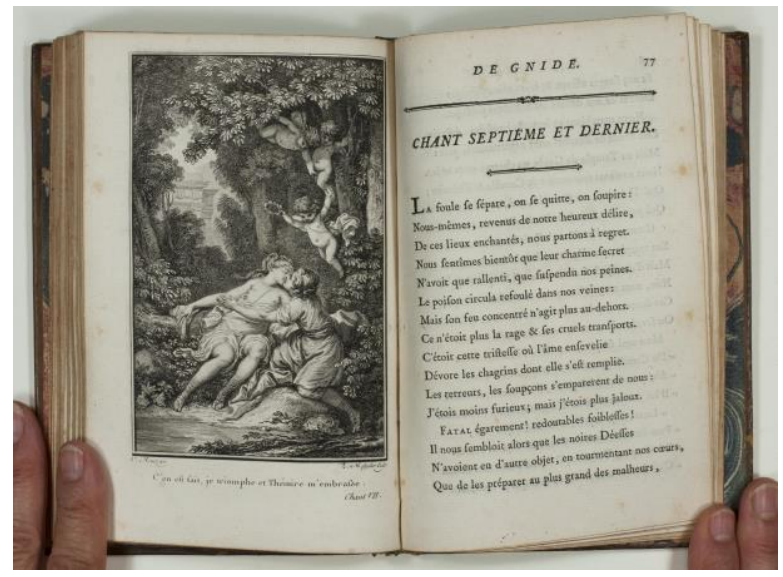

Fig. 10. Engraving from Charles-Pierre Colardeau. Le temple de Gnide [Paris, 1773]. Photograph by Marci Hahn-Fabris. Courtesy of Wellesley College Library, Special Collections.

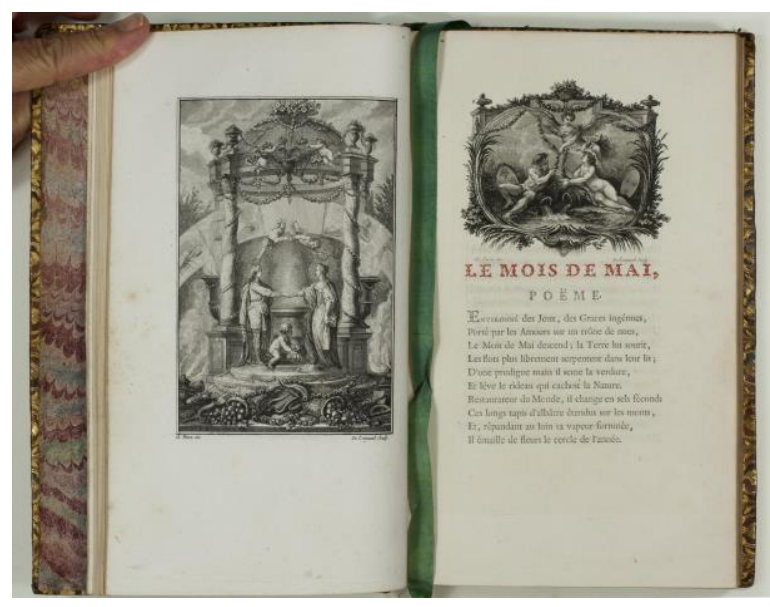

Fig. 11. Engravings and text from Claude Joseph Dorat. Les baisers, précédés du Mois de mai [Paris, 1770]. Photograph by Marci Hahn-Fabris. Courtesy of Wellesley College Library, Special Collections.

With more time, or in a future course, one could delve deeper into the consumer culture of almanacs such as Le Trésor, studying related primary sources such as "gallant" novels, popular songs, rococo typographic design, and illustration. Supplemented with visits to museum collections of china, furniture, jewelry, wigs, and textiles, one could create a visual backdrop that would give the Le Trésor des Graces meaningful context in the material world of preRevolutionary French society. Of course, this is only one stratum of a highly privileged segment of the population at the time. I can imagine using the almanac as a pivotal material artifact which could generate multi- dimensional inquiry into deeper issues of class, poverty, privilege, and politics.

\section{The digital format and other perils (Perspective: Jenifer Bartle, Digital Library Services Librarian)}


Upon deciding to undertake a digital scholarship project centered around Le Trésor des Grâces almanac, Professor Bilis consulted with digital library services staff to design an assignment that would enable the creative and scholarly reuse of the digitized version of the almanac. Because the almanac had so recently been acquired and digitized, we needed to work within the existing framework of the course - originally conceived as a traditional exploration of eighteenth-century French literature and not as a digital humanities course - to incorporate an appropriate upperlevel undergraduate assignment based on content in Le Trésor des Grâces into the curriculum. Questions surrounding the extent to which we would require the students to engage with unfamiliar digital methods and techniques arose immediately.

Our initial goal was to design an assignment that would encourage the students to engage with the physical object and its digital surrogates, leveraging the power of both forms to create something new. As our discussions progressed, we understood a need to maintain focus on the primary pedagogical aim of the assignment: to enable the students to engage with her assigned pouf in a creative and scholarly manner. We converged on the idea to produce a digital exhibit that would showcase the images of the hairstyles in the almanac, along with the students' original scholarship about them, yet would make use of digital tools with which the students were already familiar. Because the structure of the course was already in place, and because significant time would need to be dedicated to the study of the almanac as a material object, we knew that dedicating additional course time to teaching unfamiliar digital publishing platforms and managing a collaborative production environment would take us too far from the pedagogical aims of the course.

We evaluated authorship and publication tools for use in this assignment based on the following criteria: ease of use; familiarity of faculty, library staff, and student authors; ease of collaboration; cost; access; flexibility; and reproducibility by other institutions.

Authoring their work in Google Docs, a commonly used platform on campus, was a natural choice and allowed students to compose their essays and translations and share them with their classmates and their professor for feedback; it also allowed them to easily share their final versions with me to enable the production of the final exhibit. This approach centered the students' creative, scholarly engagement with their unique images. It allowed them the freedom to pursue open-ended, original research, while maintaining the focus on the content, and not the final form, of the exhibit.

For the final publication platform, we considered Drupal, WordPress, Omeka, and Scalar, all of which were supported by Wellesley College Library and Technology Services (LTS) at the time. I chose to produce the final exhibit in Scalar because it is free, openly available, flexible, and excels at integrating text and images. It was a good fit for this project because it allowed us to highlight the almanac images, metadata, and the text of the students' research together with annotations, supplemental images, and hyperlinks to additional sources.

For this project, each student's assigned image and accompanying French and English essays were presented on a separate page in a Scalar "book." We took advantage of Scalar's ability to incorporate custom CSS code to design the flow of the two versions of the essays around the central image (see fig. 12), giving neither language primacy. Navigation between the pages was 
arranged in a path that replicated the order that the images appear in the original text, but could additionally be designed to allow the reader to move through the exhibit by theme or topic.

\section{Coiffure à la Mont-médy}

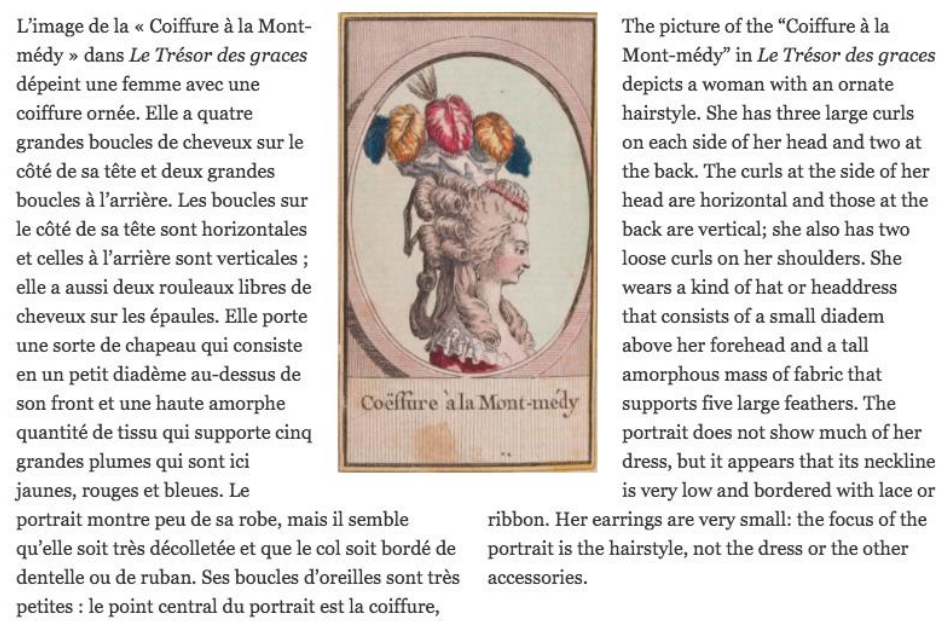

Fig. 12. Screenshot from the Des Coiffures pour l'histoire exhibit (http://scalar.usc.edu/works/des-coiffures-pour-lhistoire/coiffure-mont-medy). Each page of the exhibit contains a central image with the French and English language versions of the students' essays flowing around it. CSS code by Kara Hart, Systems Librarian, Wellesley College.

There are trade-offs when using any digital tool in a classroom setting. For this assignment, students were asked to use the primary image of their hairstyle and to incorporate supporting images to enhance their scholarly arguments. However, in Google Docs, images are embedded in a way that is inconvenient to extract them for reuse. If we were to redo this assignment, I would require students to submit their images separately, in a web-ready format such as jpeg, to make it much easier to reuse them in Scalar or elsewhere. Alternatively, a collection of images could be built in an external digital collection tool such as Omeka and then brought into Scalar using an API.

The decisions we made about the digital tools used in this assignment presented both challenges and opportunities. We admit to feeling somewhat liberated by the decision to have students use a familiar composition environment and to retain their focus on the content of the exhibit rather than on its final form. Because we shifted the final production work to library staff, we didn't need to dedicate additional time for classroom instruction and support in the use of an unfamiliar tool, nor did we need to develop workflows that would necessarily reframe the focus of the project to digital co-authorship and co-production. These are, of course, worthy pedagogical goals in their own right; we simply acknowledge that semesters are short and choices must be made.

Another benefit of shifting the exhibit production labor away from the students revealed itself when we began to see that the project replicated a collaborative model of professional scholarly communication: the students were cast as the experts, the professor served as the editor, and 
library staff focused on research support and production of the final form of the exhibit. Indeed, for student scholarship to find a continued audience in a public digital space, additional labor beyond the traditional bounds of the undergraduate classroom will likely need to occur. The affordances of web-based scholarly exhibits are many, but typically require dedicated production labor to realize fully. Synthesizing student scholarship, especially from multiple authors, into a cohesive digital exhibit requires editing, organizing, formatting, metadata creation, and likely at least basic html or CSS coding skills. In a higher education setting, this labor might be performed by a faculty member, a librarian, instructional technologist, or other digital scholarship support staff, or perhaps to paid graduate or undergraduate student workers. We were fortunate to have the ability to design a project that would continue to have resources dedicated to it once the students completed their scholarship. We also recognize that our experience raises significant issues of sustainability and ongoing support for these types of projects.

\section{Developing primary source and visual literacy (Perspective: Laura M. O’Brien, Research and Instruction Librarian)}

The assignment to explicate the engravings of this unique eighteenth-century almanac called upon the students to develop and demonstrate primary source literacy at an advanced level [see Assignment description in Appendix I] Guidelines for primary source literacy have been recently developed by a joint task force of the Society for American Archivists and the Rare Book and Manuscript Section of the Association for College and Research Libraries (SAA-ACRL/RBMS Joint Task Force on Primary Source Literacy 2017). While this course took place before these guidelines had been published in draft form, they drew, as I did, on the work of Peter Carini, among others, in conceptualizing and defining outcomes for instruction related to archives and special collections (Carini, "Archivists as educators").

Carini identifies that using a primary source in research requires "a complex understanding of the creators, the intended audience, the technology used to produce the [source], and the context of its production" (Carini, "Information literacy" 193). In the context of this assignment, students had to integrate their understanding of Ancien Régime France and the world of the court with their newly acquired knowledge from the class session with Ruth Rogers, Curator of Special Collections. All the contextual knowledge they had acquired needed to be applied to their analysis of the engraving of a coiffure, but this process was difficult for several students in the class.

In my 70-minute class session with the students, we explored steps they might take in the form of research that would help them add to their knowledge of the historical period and the material context of the almanac and its illustrations. These included locating scholarship and exploring collections of digitized primary materials for context and comparison to their engraving. Digital humanists and scholars of this historical period benefit from the wealth of digital resources available for research and reuse, largely free from copyright restrictions. I collected these resources in a research guide that directed students to these collections, including the Bibliothèque Nationale de France's Gallica digital library, the Internet Archive, and Eighteenth Century Collections Online, a subscription resource. Specific items of interest relevant to the project, such as the (likely apocryphal) memoir of Légros, Marie-Antoinette's hairdresser, illustrated volumes on the history of French fashion, or engravings of coiffures and costume 
located in digital collections from CESAR Calendar électronique des spectacles sous l'ancien régime et sous la revolution and the Museum of Fine Arts, Boston, were called out in a class bibliography shared on Zotero, which was added to over the course of the semester. Students searched these resources for clues to the inspiration for their coiffure, finding direct references where possible - but for many students, direct evidence was elusive. While the resources available for study of this period are tremendously rich, some key gaps in the students' knowledge and skill set emerged on reviewing the first draft of their analyses.

To correctly interpret an image, students must be able to answer a key question about it: what is significant about an image, and what is not? One aspect they had been trained to regard as highly significant was accompanying text. This meant that those whose engravings had distinctive text ("Coëffure à la Sémiramis", "Coëffure à la Réthel Mazarin") had a natural place to begin their research, while those who had less distinctive titles ("Coëffure au plaisir des dames," "Coëffure à la belle saison") were less certain of where to begin.

In order to determine what was significant to their analysis of the engraving, students had to recognize that there is a visual "language" being used, and that that language can be interpreted within its historical cultural context. The composition of the image, its style and subject matter compared to other similar engravings from the time period, even the knowledge that these images might well have been recycled or reused in past or future publications by the publishers or printmakers (see fig. 13 and fig. 14), as some students discovered, all is relevant to developing their visually literate "reading" of the image. ${ }^{9}$ 


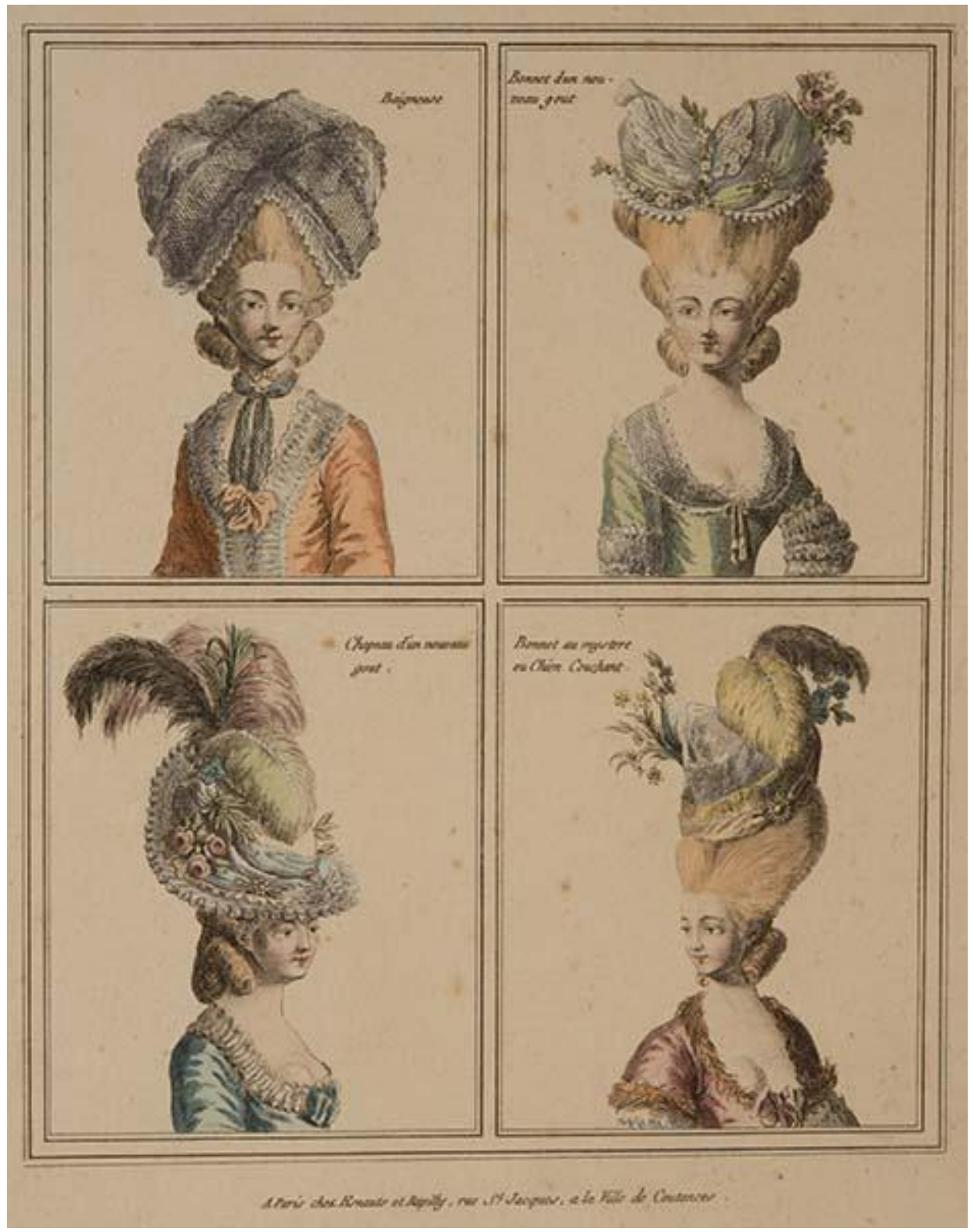

Fig. 13. Artist unknown, Fashionable Hats and Bonnets. Hand-colored etching sheet: $1415 / 16 \mathrm{x}$ $107 / 16$ in. (37.9 x $26.5 \mathrm{~cm})$; platemark: $107 / 8$ x $87 / 8$ in. $(27.6$ x $22.5 \mathrm{~cm})$. Image courtesy of the Davis Museum at Wellesley College, Wellesley, MA, Gift of Mrs. William B. Heller (Anne Cohen, Class of 1941) in the Name of the Class of 1941. 


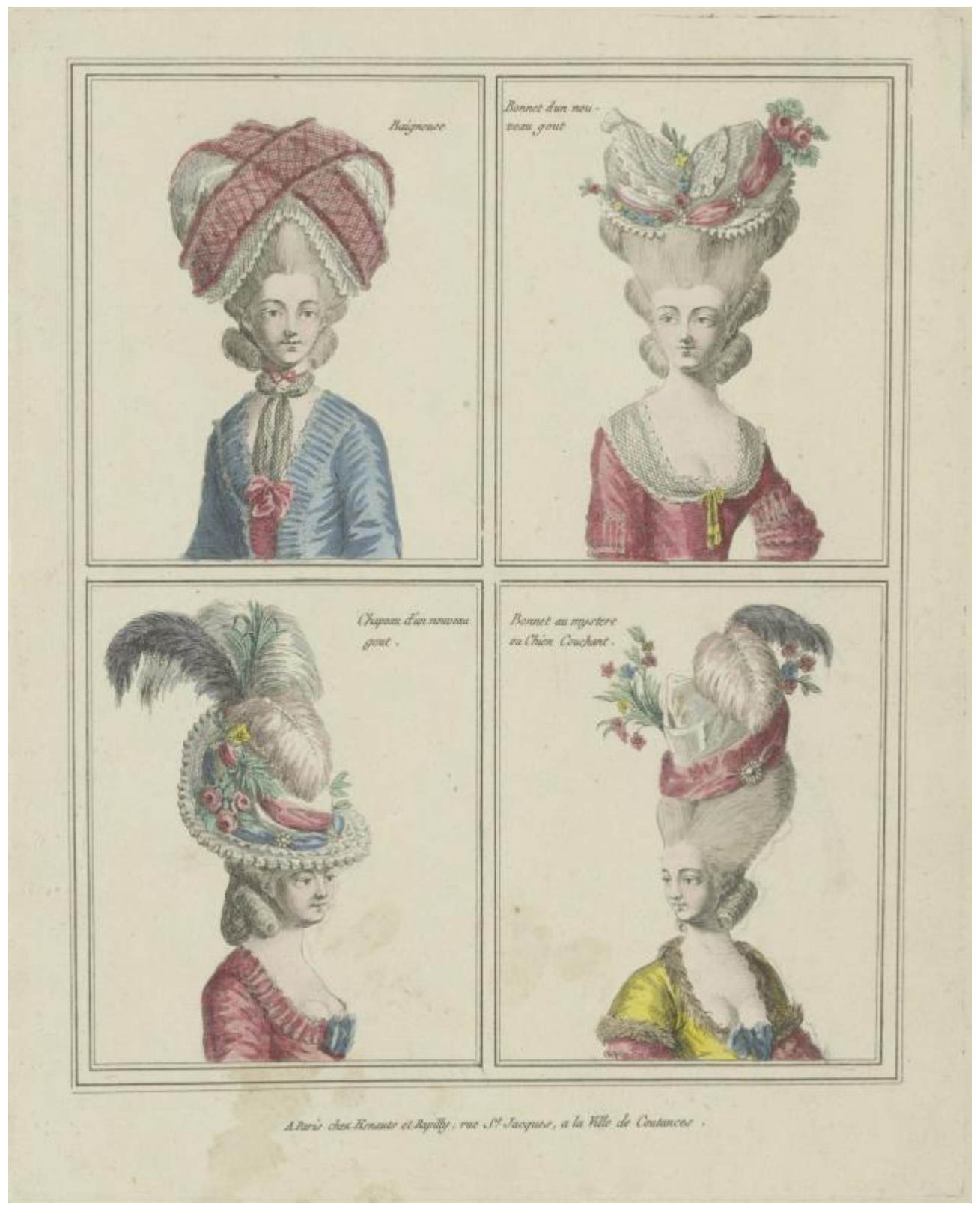

Fig. 14. Esnauts et Rapilly (Paris). Gallery of Fashion et Du Costume Français: Baigneuse, Bonnet d'un Nouveau Gout, Bonnet Au Mysteres Ou Chien Couchant. B.11. ca 1778, (http://www.smb-digital.de/eMuseumPlus?objectId=1877994). Image courtesy Anna Russ and the Kunstbibliothek der Staatlichen Museen zu Berlin, used under Creative Commons license BY-NC-SA 3.0 DE.

Consequently, one crucial area of instruction I provided to students as they pursued their research projects was in some basic methods of visual analysis. Those students who had backgrounds in art history or cinema and media studies understandably came to this more readily than those who had not had similar training. In the absence of textual evidence from a reference source or some other clear inspiration, we prompted students to focus on what they could discern from the image itself. Is the hairstyle ornate or relatively simple? Is the primary decoration 
flowers or jewels? What is its general shape, and is that shape suggestive or emblematic? How does this engraving fit into the context of other engravings from the period on similar themes? During consultation with a student we could provide assistance in the form of Socratic questioning and by suggesting resources to mine for visual or textual comparison to help them contextualize their close reading of the image (Robinson).

An excellent example of a visual analysis by a student demonstrates the complex understanding of cultural context and visual literacy some students were able to achieve:

The model is seated in three-quarters profile, much like other drawings in the almanac. However, unlike the majority of the drawings in Le Trésor, the model makes eye contact with the reader: she gives them a voluptuous smile and blushes as she meets their eyes. It is interesting to note that she is depicted in a more seductive manner than other models in the almanac. Her breasts extend above the neckline of her dress, which is made of the same fabric as her cap. This portrait evokes the idea of the seductive beauty of nature, like a shepherdess with her flock. The simplicity of the hairstyle represents, on the one hand, the aristocratic demography and the geography of [the Rethel-Mazarin] duchy at this time.

While the student provides a basic visual description of the engraving of the "Coëffure à la Réthel Mazarin", she also clearly uses contextual knowledge of the period and other images from the almanac to identify significant visual elements of the portrait that contribute to its meaning (the smile, the décolletage, the simplicity of the hairstyle). The result is an analysis that is research-supported but absolutely original. Providing this style of visual literacy instruction to students - an extension of the traditional library research support-opens further avenues for productive research and analysis.

\section{The Shape of the Project and Assessment (Perspective: Hélène Bilis, French Faculty)}

The students embraced the assignment beyond our expectations. They took on the role of historian-reader-detective and enjoyed reporting back to the class on what they had found, as if sharing a lead on a mystery case. During the four weeks when the students were actively researching their images, I dedicated 10-15 minutes at the start of every class session to having them share their obstacles, uncertainties, and discoveries along the way. This was a good way to gauge their progress. Students commented that the assignment made them recognize the importance of interdisciplinary studies, valuing how their knowledge of French dovetailed with a better understanding of history, and they acknowledged a growing awareness of the methods and vocabulary of the visual arts.

A sample of two entries linked here underscore the variety of students' discoveries and the insight they brought to the project:

- Coiffure à la Mont-médy by Charlotte Treadwell

(http://scalar.usc.edu/works/des-coiffures-pour-lhistoire/coiffure-mont-medy)

- Coiffure à la Villers by Laurel Kinman

(http://scalar.usc.edu/works/des-coiffures-pour-lhistoire/coiffure-villers) 
We encourage our readers to http://scalar.usc.edu/works/des-coiffures-pour-lhistoire/index which includes all of the student entries listed one by one; a "Gallery of the Hairstyles," where every engraving in Le Trésor is available; a short introduction to the project written by the students and their professor; "A Brief Case Study," an initial reflection on our cross-campus collaboration (and the impetus for the present essay); and additional research by students on related topics. The Appendices to this essay include the assignment itself, with interpolated discussion of the workflow, as well as our assessment rubric.

Beyond the time constraints of the semester, the biggest difficulty, in the end, was the assessment of their entries. Students received separate grades for content and language components, which I then combined into one full grade (50 pts for French Language and 50 points for Content). Students wrote their entries first in French, which went through multiple drafts; if at the end of this process there are any remaining problematic expressions or grammatical issues, I highlight them in the working Google doc and comment on the error so the student can see the changes I make. In most cases, the student fixes these. In the rare case, when she does not, I fix it myself after having assigned her grade. The project would have to be bilingual to be accessible to English- and French-speaking audiences, but also for the assignment to maintain the linguistic benefits of a foreign language course. I designated their English versions as either "Completed" or "Still needs revision." I chose to give them credit for completing this portion of the assignment rather than trying to reward those with the best English writing style. Although this was not a translation course and we did not have time to delve deeply into advanced techniques of translation, students reported that the exercise was eye-opening for spotlighting their linguistic tics in French and English and for thinking about their writer's voice in both languages. Inevitably, as I assessed their translations for accuracy, I came upon turns of phrase or formulations I would not have chosen myself, but I decided to edit their English lightly and only when absolutely needed to better capture the variety of student writing inherent to a group project.

Some questions arose for us around the question of completeness and the level of correction we would ask of the student entries. Our working principle was that neither Jen Bartle nor I would edit their work without making them aware of our corrections and the reasons for them. Since our digital exhibit is an undergraduate project accomplished over the course of one semester, I did not think it was necessary to alter student work beyond asking them for corrections and accuracy. Although I believe the students' research is of high caliber, it would not undergo a peer-review process. They had an incentive to make their entries strong since they were working for a course grade. I made it clear to them from the outset that there was a bar they needed to reach for their work to be considered complete and publishable as part of our exhibit. For some students, reaching the "completed" level took longer than others, but I emphasized repeatedly that this kind of group project might mean going down some dead ends, making some wrong turns, and writing multiple drafts. Since their grade depended on having finished all the sections of the assignment, students had strong motivation to keep working on their entry until they and I could declare it finished.

Grading the content of the entry was much more difficult since students had been required to consult with Laura M. O’Brien and since some entries were more straightforward than others 
because the hairstyle's reference was more explicit. In addition, since we would be publishing the entries on the Scalar site, everyone needed to reach an advanced degree of research expertise before we could deem the entry "web-ready." "Effort," therefore, became an important part of the assignment's evaluation. I considered the thoroughness of their investigation into potential sources, the quality of the links they included, their respect of assignment directives, and the logic of their explanations. In constructing my grading rubric, I drew from Shannon Christine Mattern on evaluating digital projects, although since my students were not responsible for designing the digital exhibit themselves, the rubric I used was substantially shorter. ${ }^{10}$ It should be said that in this component, the grades were all quite high, even if some students had to go through more drafts than others.

In future iterations of such a project, I plan to ask students to write a final reflective piece on their contributions to the digital group project. Building in a meta-reflective component will encourage them to think explicitly about the process itself and the ways the digital format affected their choices and methods. Drawing on pedagogy on the value of including metacognitive components for experiential learning, I am convinced they will better articulate the skills and understanding they gained from working on the group digital project.

We felt the project and the students' attitude towards it had proven successful. The end of semester evaluations attested to their sense of discovery and excitement. Students described the project as "one of the best things I've done in college," "so insightful," and "so eye-opening": a whopping 12 out of 12 students "highly recommended" the course. The skills they honed over the course of this assignment differed from those of the research essay. Students focused on writing concisely, meeting project deadlines, following directives for content and sources, and above all, working collaboratively. Perhaps the lesser focus on grades contributed to the more jovial attitude I encountered among the students throughout the process. Or perhaps their joviality was linked to our repeated use of the word "pouf."

\section{Conclusions (Perspective: Hélène Bilis, French Faculty)}

I plan to return to Le Trésor des Grâces for future projects. We still need to investigate the "wins and losses" pages and gain a clearer understanding of the texts within the almanac, especially the songs, investigating whether they relate to the hairstyles. At this writing, I have taught the course again once and did not dive back into the all-hands-on-deck-mentality required from students, faculty, and library partners for undertaking such a project. Despite the unfailing investment from my colleagues, I did not feel like I could ask them to reboot their efforts for another project quite so quickly. This kind of project is labor intensive for all involved, much more time consuming than working from a traditional syllabus, directing class discussions of our readings, and preparing essay questions. It was a valuable experience, a project that lives on because students and colleagues can turn to it. For instance, in the most recent iteration of the course, I incorporated our exhibit into the course readings. My new students engaged with their peers' work and used our project as a resource for their own understanding of Marie-Antoinette and her milieu. Nonetheless, it takes stamina from faculty and library partners to bring such a project to conclusion in one semester. 
Our experience with the Trésor des Grâces project has taught us to seek out ways of inviting students to actively reflect on the connections between the content they are reading and the medium in which it is delivered to them. Rather than inserting a digital project into a pre-existing syllabus, we hope in the future to design a course from scratch that tries to integrate digital methods and scholarship with early modern texts from the start so that students take into account the benefits and drawbacks of new technologies in the classroom. Instead of an (exciting) add-on that diverges from the traditional essay, we will aim to have students reflect critically — and explicitly_ on the tools at their disposal and the value of digital projects for learning about early modern France.

Finally, beyond its permanent digital home on the Special Collections website and its feature on Wellesley's Blended Learning Initiative homepage the project was included in an article in the Notes \& Queries section of Journal18. It is an exciting development for any undergraduate to have her work showcased in such a venue.

More than any salvo I or other faculty could make on the worthiness of the humanities, the success of the exhibit garnered great enthusiasm from the students about their work. They told me they had shared it with their families and discussed it at lunch with their friends. Academically, they gained insight into the worthiness of consulting Special Collections and not relying solely on digital versions of materials and texts. They grasped how

towering poufs became a medium in which diplomatic, economic, and social practices such as attending the theater, playing at herding sheep, or commemorating a treaty could be celebrated. Deciphering these poufs enabled students to recognize the cultural messages carried by the queen's hair in the eighteenth century and prompted them to reflect on the communicative power of the body across time.

Most of my students are double majors and few have plans to attend graduate school in the humanities. Writing a long research paper with a long bibliography on a topic they are moderately invested in can have limited gains in stimulating their engagement with the content and period in the long term. Even the most promising French major today considers knowing the "French canon" less of a priority than her counterparts did even ten years ago. Students want to make connections between texts in their French courses and classes in other departments; they want to chart evolutions and trends rather than imbibe texts their instructors have told them all self-respecting majors must know. Certainly, the students in the essay version of the course finished with better French grammatical skills and a greater sense of the slow and careful work that makes a good thesis and analytical argument. These are qualities I value deeply and eagerly returned to teaching in the latest iteration of the class. Nonetheless, the students in the digital project version of the course walked away with more excitement for the doors French courses could open for them. They knew less about the major authors and works of the period, although they were not clueless about them either, but they arguably understood the cultural climate and the mentalité of the era regarding women in power better than their essay-writing peers. Both approaches have their tradeoffs: I will continue teaching both versions.

From the instructor's perspective, it was invigorating to go off the tracks of the syllabus and venture into the territory of what an object in Special Collections could reveal. I emphasize the enormous time component spent communicating between partners by email and in person. For 
such projects it is crucial, indeed, to have a clear communication between the partners, making certain everyone is aware of the tasks that have been accomplished and the tasks that remain, and how those tasks are divided. A shared master document noting the steps towards completion is essential. This tracking of the progress can be done formally through a carefully written out document or informally with just a few bullet points, but everyone, including the students, should know what has been accomplished and what remains before completion. The biggest adjustment is the collaborative nature of digital projects. The time I usually devote to writing reading guides for students or essay prompts shifted into group discussions with the library colleagues on digital formats and divisions of tasks. At the end of the semester, instead of a stack of papers to grade, I had a link to our digital exhibit produced by Jenifer Bartle. Our sense of accomplishment was more palpable than in any course I had previously taught. We hope colleagues, graduates, and undergraduates will enjoy browsing through our exhibit as much as we enjoyed its collaborative composition.

\footnotetext{
${ }^{1}$ See Eodice et al., who argue that their study of meaningful forms of writing shows that undergraduate seniors most value public digital projects because they see them as fostering agency, engagement, and learning for transfer in the students' anticipated future tasks and selves.

${ }^{2}$ Vanpée designed a first year seminar on Marie-Antoinette and eighteenth-century material culture. She created a variety of digital assignments to encourage undergraduates to reflect on early modern objects and how they shape our understanding of history and culture. Mussachio and her students moved between primary sources (letters, historical maps) and digital tools (timelines, visualizations, and digital maps) to explore the correspondence of Ann Whitney during her travels in Europe in the late nineteenth century:

omeka.wellesley.edu/annewhitney/neatline/show/overview.

${ }^{3}$ See Bilis and Visentin on creating assignments in the French literature classroom around a digital platform.

${ }^{4}$ On the Candide edition, see Cronk and Chautemps: https://candide.bnf.fr/livre\#1. On the Folger edition, see https://www.folger.edu/folger-shakespeare-library-editions.

5 See also Melzer and Norberg, Editors. From the Royal to the Republican Body.

${ }^{6}$ See also Goodman, Marie-Antoinette: Writings on the Body of a Queen.

7 This account loosely summarizes Lise Andries, "Almanacs: Revolutionizing a Traditional Genre."

8 There are several sites that have repackaged the plates from Diderot's Encyclopédie into more classroom-friendly versions, including ARTFL's Encyclopédie project (in French), and the Victoria \& Albert Museum's interactive tool to explore the trades displayed in the Encyclopedia (in English).

${ }^{9}$ A more complete listing of learning outcomes relevant to the analysis of historical images can be found in Standard Three of the ACRL Visual Literacy Competency Standards.

10 See Mattern on how to assess projects, define evaluative criteria, and give useful feedback to students on multi-modal projects.
}

\section{Appendix I}

The following is a translated version of the assignment given to students in this course with commentary on the project's workflow.

\section{Deciphering the Trésor's engravings}

(First version in French)

You will serve as the expert for the engraving assigned to you. You will track down all the information you can find on the image and on the reference made by its accompanying title so 
that a reader of the almanac in Special Collections or a browser of our digital exhibit on the internet will understand what the hairstyle references.

Elements to include in your entry (between 750 and 900 words):

1. A portrait description: What does the image show? What are the details to notice (i.e., styling of the hair, accessories, woman's gaze, dress, hands, body placement, etc.)? How does this image differ from others? What aspects conform to the overall style of Le Trésor's poufs?

[This first section was completed as Part One of the assignment, due after three class sessions dedicated to discussing the Trésor des Grâces specifically and almanac history more generally. In separating this section from the research component of the entry, students perfected their French vocabulary and their visual analysis skills. They needed to pay sustained attention to the image itself, rather than to its title or textual clues. The description component, completed first in French and then translated into English, was useful for them to focus on what they saw and to point out what an eventual visitor should be sure to notice.]

2. Uncovering the title's reference: This will be the longest section since you will describe your research findings. Explain the historical contexts or cultural allusions needed to understanding the image. Address your hypotheses or competing interpretations.

3. Link to larger object: Why would this hairstyle appear in an almanac destined to MarieAntoinette? What interpretation can you offer for its presence in Le Trésor des Grâces?

4. Additional resources: What links, images or resources have you included to heighten viewers' grasp of the engraving? Include links with bibliographical sources at the end of your description. Make sure the links work and that you are citing your sources in proper format.

You will complete this assignment in dialogue with your professor, your classmates, and Laura O'Brien, who will help you find sources for interpreting your engraving. Jenifer Bartle will take on the heavy task of compiling your entries, formatting, and posting them on the Scalar platform.

[We gave the students three and a half weeks to fully complete this section. They undertook initial research on the title, consulting the web and library holdings. Then, they attended a mandatory individual meeting with Laura O'Brien who helped them track down sources that could be relevant, including maps, songs, other almanacs, etc. They discussed their findings in class, including their ambivalences and challenges, sharing feedback with each other. They then wrote up \#2-4 as Part 2 of the assignment and pasted it onto the Google Doc where the completed Part 1 was already finished.]

\section{Appendix II: Rubric for grading student entry content for digital exhibit (inspired by Shannon Mattern's "Evaluating Student Multimodal Work”)}

- Does the entry reflect an understanding of the target audience through its tone, vocabulary, and descriptions? (10 pts)

- Does the entry have a clear and logical organization of content and ideas, and does it include all the elements laid out in the assignment guidelines? (10 pts) 
- What is the quality of resources used? Does the entry use a variety of types of resources (book chapters, journal articles, archival documents, images, sound and other media)? (10 pts)

- Does the entry exploit the digital possibilities effectively (drawing from web sources, incorporating working links, sound choices in visual selection)? (10 pts)

- Does the entry include proper citation and photo credits? (10 pts) 


\section{Works Cited}

Andries, Lise. “Almanacs: Revolutionizing a Traditional Genre." Revolution in Print: The Press in France, 1775-1800, edited by Robert Darnton and Daniel Roche, U of California P, 1989, pp. 203-222.

ARTFL Encyclopédie. http://encyclopedie.uchicago.edu/. Accessed 25 Jan. 2018.

"ACRL Visual Literacy Competency Standards for Higher Education." Association of College and Research Libraries, 27 Oct. 2011, www.ala.org/acrl/standards/visualliteracy.

Bilis, Hélène, and Jenifer Bartle. "Between Hairstyle and History: Marie-Antoinette's Almanac." Journal18: A Journal of Eighteenth-Century Art and Culture, 30 May 2017, http://www.journal18.org/nq/between-hairstyle-and-history-marieantoinettes-almanac-by-jenifer-bartle-helene-bilis/.

Bilis, Hélène, and Hélène Visentin. "Pedagogical Exercises Using Database Visualizations Drawn from the Comédie-Française Registers Project." The Comédie-Française Registers Project, http://cfregisters.org/en/teaching-resources.

Carini, Peter. "Archivists as Educators: Integrating Primary Sources into the Curriculum.” Journal of Archival Organization, vol. 7, no. 1-2, May 2009, pp. 41-50.

---. "Information Literacy for Archives and Special Collections: Defining Outcomes." Portal: Libraries and the Academy, vol. 16, no. 1, Feb. 2016, pp. 191-206, doi.org/10.1353/pla.2016.0006.

Chamonal, Rodolphe. Livres anciens. Chamonal, 2014. www.chamonal.com/sites/www.chamonal.com/files/201611/2014\%2012\%20Varia.pdf. Accessed 15 June 2018.

Colardeau, Charles-Pierre, and Charles de Secondat Montesquieu. Le Temple de Gnide. Jay, 1773.

Cronk, Nicholas, and Alexandre Chautemps. « Candide. Éditer et (re)lire les classiques en numérique », Revue de la BNF, vol. 42, no. 3, 2012, pp. 29-35.

Darnton, Robert. Poetry and the Police: Communication Networks in Eighteenth-Century Paris. Harvard UP, 2010.

DeJean, Joan E. The Essence of Style: How the French Invented High Fashion, Fine Food, Chic Cafés, Style, Sophistication, and Glamour. Free Press, 2005.

Diderot, Denis, and Jean-Baptiste le Rond D'Alembert. Encyclopédie, en 17 vol. de textes et 11 de planches, entreprise sous la direction de Diderot et d'Alembert, avec 
l'aide d'une centaine de collaborateurs. Inter-livres, 1751. gallica.bnf.fr, http://gallica.bnf.fr/ark:/12148/bpt6k99717.

Dorat, Claude Joseph. Les Baisers: Précédés Du Mois de Mai. Lambert et Delalain, 1770.

Eodice, Michele, et al. The Meaningful Writing Project: Learning, Teaching, and Writing in Higher Education. Utah State UP, 2016.

Gaskell, Philip. A New Introduction to Bibliography. Clarendon Press, 1972.

Genette, Gérard. Paratexts: Thresholds of Interpretation. Translated by Jane E. Lewin, Cambridge UP, 1997.

Goodman, Dena, editor. Marie-Antoinette: Writings on the Body of a Queen. Routledge, 2003.

---. The Republic of Letters: A Cultural History of the French Enlightenment. Cornell UP, 1994.

Grand-Carteret, John. Les Almanachs Français: Bibliographie, Iconographie Des Almanachs, Années, Annuaires, Calendriers, Chansonniers, Étrennes, États, Heures, Listes, Livres D'adresses, Tableaux, Tablettes, et Autres Publications Annuelles Éditées À Paris, 1600-1895. Slatkine Reprints, 1968.

Hosford, Desmond. "The Queen's Hair: Marie-Antoinette, Politics, and DNA." Eighteenth-Century Studies, vol. 38, no. 1, 2004, pp. 183-200.

Hunt, Lynn. "The Many Bodies of Marie-Antoinette: Political Pornography and the Problem of the Feminine in the French Revolution." Eroticism and the Body Politic, edited by Lynn Hunt, Johns Hopkins UP, 1991, pp. 108-130.

Les Intrigues de la capitale, accompagnées de plusieurs autres. [Illustrée par Louis Binet] Paris: chez Jubert, 1788.

Lilti, Antoine. Figures Publiques: L'invention de La Célébrité, 1750-1850. Fayard, 2014.

Lyons, Martyn. A History of Reading and Writing: In the Western World. Palgrave Macmillan, 2010.

Mattern, Shannon Christine. "Evaluating Multimodal Work, Revisited," Journal of Digital Humanities, vol. 1, no. 4, Fall 2012, http://journalofdigitalhumanities.org/1-4/evaluating-multimodal-work-revisitedby-shannon-mattern/. 
Melzer, Sara E., and Kathryn Norberg, editors. From the Royal to the Republican Body: Incorporating the Political in Seventeenth-and Eighteenth-Century France. U of California P, 1998.

Musacchio, Jacqueline M. 'Mapping the 'White, Marmorean Flock': Anne Whitney Abroad, 1867-1868." Nineteenth-Century Art Worldwide, vol. 13, no. 2, Fall 2014, omeka.wellesley.edu/annewhitney/neatline/show/overview.

Partridge, John. Merlinus Liberatus: Being an Almanack for the Year of Our Saviour's Incarnation, 1693. and from the Creation of the World according to the Best of History, 5642. It Being the First after Bissextile, or Leap-Year. And the Fifth of Our Deliverance from Popery and Arbitrary Government. In Which Is Contained Things Fit for Such a Work: As the Diurnal Motion of the Planets, Remarkable Conjunctions, Lunations, Eclipses, Meteorological and Astrological Observations. A Table of the Sun Rising and Setting, \&c. to Every Sixth Day in the Year. A Judgment on the Four Quarters. And the Present Impending Directions in the French Tyrants Nativity, with Some Remarks Thereon: Not Forgetting My Old Friend J.G. . . By John Partridge, Student in Physick and Astrology. printed by R. Roberts for the Company of Stationers, 1693.

Préaud, Maxime. Les Effets Du Soleil: Almanachs Du Règne de Louis XIV. Réunion des Musées Nationaux, 1995.

Robinson, Shannon. "Socratic Questioning: A Teaching Philosophy for the Student Research Consultation." In the Library With the Lead Pipe, 1 Nov. 2017, www.inthelibrarywiththeleadpipe.org/2017/socratic-questioning/.

SAA-ACRL/RBMS Joint Task Force on Primary Source Literacy. Guidelines for Primary Source Literacy. 24 June 2017, http://connect.ala.org/node/267589.

Thomas, Chantal. La Reine Scélérate: Marie-Antoinette Dans Les Pamphlets. Editions du Seuil, 1989.

Vanpée, Janie. "Creating an Online Exhibit in a First-Year Seminar: 'Luxury Objects in the Age of Marie Antoinette.'" ABO: Interactive Journal for Women in the Arts, 1640-1830, vol. 3, no. 1, article 4, 2013. http://scholarcommons.usf.edu/abo/vol3/iss 1/4.

Victoria and Albert Museum. "Design a Wig." V\&A Design a Wig, www.vam.ac.uk/designawig/. Accessed 23 Jan. 2018.

---. V\&A Trades - Object: Book. www.vam.ac.uk/europetrades/\#/object/book. Accessed 25 Jan. 2018.

Weber, Caroline. Queen of Fashion: What Marie Antoinette Wore to the Revolution. Picador, 2007. 
Wellesley College Special Collections. Between Hairstyle and History: Understanding the Engravings in Marie-Antoinette's Almanac, Le Trésor Des Graces [Des Coiffures Pour L'histoire: Un Descriptif Des Gravures Dans L'almanach de Marie-Antoinette, Le Trésor Des Graces]. 12 July 2016, scalar.usc.edu/works/des-coiffures-pour-lhistoire/index.

Zanger, Abby E. Scenes from the Marriage of Louis XIV: Nuptial Fictions and the Making of Absolutist Power. Stanford UP, 1997. 